\title{
Antimicrobial Activity of Calcium Hydroxide Pastes on Enterococcus faecalis Cultivated in Root Canal Systems
}

\author{
Patricia Elaine Panicali LANA ${ }^{1}$ \\ Miriam Fatima Záccaro SCELZA ${ }^{1}$ \\ Licínio Esmeraldo SILVA ${ }^{2}$ \\ Ana Luíza de MATTOS-GUARALDI ${ }^{3}$ \\ Raphael HIRATA JÚNIOR ${ }^{3}$ \\ ${ }^{1}$ Department of Endodontics, Fluminense Federal University, Niterói, RJ, Brazil \\ ${ }^{2}$ Institute of Mathematics, Fluminense Federal University, Niterói, RJ, Brazil \\ ${ }^{3}$ Department of Microbiology, Immunology and Parasitology, School of Medical Sciences, \\ State University of Rio de Janeiro, Rio de Janeiro, RJ, Brazil
}

\begin{abstract}
The effectiveness of calcium hydroxide pastes: Calen ${ }^{\mathrm{TM}}$ and PMCC-Calen ${ }^{\mathrm{TM}}$ associated to chemo-mechanical preparation was assessed on Enterococcus faecalis grown within root canals. Seventy incisors were inserted into TSB medium, sterilized and contaminated with E. faecalis. Culture medium was replaced each $24 \mathrm{~h}$ and incubated at $37^{\circ} \mathrm{C}$ for $72 \mathrm{~h}$. After chemo-mechanical preparation, root canals were filled with Calen ${ }^{\mathrm{TM}}$ or PMCC-Calen ${ }^{\mathrm{TM}}$ ( 7 or 14 days). Pastes were removed and teeth were inserted into test tubes containing Enterococcosel broth. Calen ${ }^{\mathrm{TM}}$ paste (maintained for 7 and 14 days) induced $70 \%$ elimination of enterococci and PMCC-Calen ${ }^{\mathrm{TM}} 100 \%$ elimination only after maintenance for 14 days. These medications were significantly more effective $(p<0.001)$ than chemo-mechanical protocol alone and PMCC-Calen ${ }^{\mathrm{TM}}$ maintained for 7 days, both incapable to eliminate the viability of enterococci. Calcium hydroxide pastes demonstrated important adjuvant effects in the elimination of enterococci during chemo-mechanical preparation of root canal systems. When associated with PMCC, calcium hydroxide pastes should be maintained for at least 14 days.
\end{abstract}

Key Words: calcium hydroxide, chemo-mechanical preparation, Enterococcus faecalis.

\section{INTRODUCTION}

Microorganisms and microbial products present in root canal systems are responsible for progression or maintenance of periradicular inflammatory lesions (1). Improvements in chemo-mechanical techniques and filling materials containing chemicals to eradicate microorganisms from dentinal walls have enhanced the success of endodontic therapy in the last 30 years. Several investigations (2) have shown advantages in one-visit endodontic treatment, reducing the need of two or more appointments, thus eliminating the use of intracanal medications between sessions, which is an additional step performed with the use of chemicals with antimicrobial properties.
The persistence of microorganisms after endodontic therapy can be responsible for treatment failure. $E n$ terococcus faecalis are enteric facultative Gram-positive cocci frequently associated with persistent endodontic infections (3). In addition to several virulence factors displayed by this species, E. faecalis isolates expressed varied resistance patterns to some agents used as intracanal medications including calcium hydroxide pastes (4). Resistance was particularly observed when tests were performed with planktonic cells grown in liquid media or in agar plates (5). E. faecalis grown in biofilms in flow cell system demonstrated elevated resistance to $2 \%$ chlorhexidine gel, and REDTA, and other chemical compounds, remaining susceptible to $6 \%$ sodium hypochlorite solution (6). 
Calcium hydroxide based intracanal medications are recommended for varied clinical situations including treatment of apical periodontitis. Although previous studies have established that enterococci are generally resistant to calcium hydroxide dressings (4), attempts to enhance the effectiveness of calcium hydroxide pastes have been proposed with addition of chemicals such as p-chlorophenol and chlorhexidine (7).

The aim of this study was to analyze the in vitro antimicrobial activity of 2 formulations of calcium hydroxide pastes (Calen ${ }^{\mathrm{TM}}$ and Calen with p-chlorophenol - PMCC-Calen ${ }^{\mathrm{TM}}$ ) as adjuvant medications to chemomechanical procedures on E. faecalis grown in contact with dentinal walls of root canal systems.

\section{MATERIAL AND METHODS}

The intracanal medications tested in this study were: calcium hydroxide paste with propylene glycol vehicle (PEG) - Calen ${ }^{\mathrm{TM}}$ (SS White Artigos Dentários Ltda., Rio de Janeiro, RJ, Brazil); and calcium hydroxide paste with propylene glycol and p-chlorophenol - PMCC Calen $^{\mathrm{TM}}$ (SS White Artigos Dentários Ltda.). The calcium hydroxide pastes were commercially obtained and used in this investigation in such a way to avoid variations during handling procedures.

Enterococcus faecalis strain ATCC 29212 was maintained in stock culture at $-80^{\circ} \mathrm{C}$ in Tripticase Soy Broth (TSB; Difco Laboratories Inc., Detroit, MI, USA) containing 25\% glycerol (Merck, Darmstadt, Germany). Microorganisms were grown on Tripticase Soy Agar (TSA-Difco Laboratories) plates, and checked for purity before contamination of teeth.

Seventy extracted single- rooted teeth (mandibular incisors) were cleaned and stored until use in $0.1 \%$ thymol solution. Root canals were accessed and working length was determined radiographically by inserting size10 K-file (Maillefer, Ballaigues, Switzerland) into the canals, which were then enlarged up to a $25 \mathrm{~K}$-file (Maillefer). The external tooth surfaces were sealed with 2 layers of quick-setting cyanoacrylate ester adhesive (Super Bonder ${ }^{\circledR}$ Instant Adhesive, Loctite Corp., Rocky Hill, CT, USA).

Contamination of teeth was based on experiments performed as described elsewhere (8). Briefly, the teeth were inserted into test tubes, covered with TSB and autoclaved. Test tubes were contaminated with $E$. faecalis $\left(10^{9} \mathrm{cfu} \mathrm{mL}^{-1}\right)$ and incubated $36^{\circ} \mathrm{C}$ for $24 \mathrm{~h}$. The culture media were removed with sterile plastic pipettes and substituted 3 times each $24 \mathrm{~h}$ incubation to ensure the growth of bacterial strain within root canals in the presence of freshly prepared culture media.

The experiments were performed in a laminar flow chamber. Teeth with $E$. faecalis growth were removed from test tubes, pulp chambers were sealed with a temporary sealer agent (Coltosol; Coltene-Whaledent Cuyahoga Falls, OH, USA), and teeth were immersed in a $5.25 \% \mathrm{NaOCl}$ solution (Formula \& Ação Farmácia, São Paulo, SP, Brazil) for $2 \mathrm{~min}$, cleaned externally with sterile gauze to remove external bacterial accumulation and immersed in sterile $1 \%$ sodium tiosulphate solution, for $1 \mathrm{~min}$ to neutralize residual $\mathrm{NaOCl}$.

The temporary pulp chamber sealer agent was removed and canal instrumentation was performed according to a crown-down technique with K-files (Maillefer) up to a size 45 master apical file with irrigation between files with $5.25 \% \mathrm{NaOCl}$ solution. After instrumentation, smear layer was removed with $20 \mathrm{~mL}$ of $10 \%$ citric acid followed by a final irrigation with $20 \mathrm{~mL}$ of distilled water (Formula \& Ação Farmácia).

The canals were then dried with sterile paper points and the teeth ( $\mathrm{n}=10$ per group) were subjected to different treatments: Group 1 - teeth without medication; Group 2 - teeth were incubated with Calen ${ }^{\mathrm{TM}}$ paste for 7 days; Group 3 - teeth receiving Calen ${ }^{\mathrm{TM}}$ paste for 14 days; Group 4 - teeth were incubated with PMCC Calen ${ }^{\mathrm{TM}}$ paste for 7 days; Group 5 - teeth receiving PMCC Calen ${ }^{\mathrm{TM}}$ paste for 14 days. Thereafter, calcium hydroxide pastes were removed by irrigation with sterile saline. Subsequently, the pulp chambers were sealed and teeth were once more decontaminated externally with sodium hypochlorite, and neutralized with sodium tiosulphate, as described above. Pulp chamber sealers were removed aseptically, and teeth immersed in enterococcosel (enterococci selective) medium without vancomycin (9). The presence of E. faecalis was also confirmed by resistance to $40 \%$ bile, fermentation of esculin, and growth in presence of $6.5 \% \mathrm{NaCl}$. Control groups consisted of teeth ( $\mathrm{n}=10$ per group) subjected to chemo-mechanical preparation incubated with sealed pulp chamber after external decontamination (negative control for elimination of enterococci viability from external root surface), and after chemo-mechanical preparation incubated in $100 \%$ humidity for 14 days (positive viability control). 
Intracanal medication agents were also tested by agar diffusion method (10). Briefly, calcium hydroxide pastes were dispensed into $6 \mathrm{~mm}$ wells performed with a puncher. Substances were tested on Mueller-Hinton agar plates (Difco) previously inoculated with an E. faecalis suspension adjusted to $0.5 \mathrm{MacFarland}$ nephelometer. Inhibition zones around medications were measured after incubation for $37^{\circ} \mathrm{C}$ for $24 \mathrm{~h}$.

The study protocol was approved by the Research Ethics Committee of Fluminense Federal University, Brazil. Statistical analysis was performed for E. faecalis elimination groups (i.e., positive results and negative elimination groups) using the chi-square test. Comparisons of the inhibition zones obtained by

Table 1. Elimination (\%) of E. faecalis from root canal systems after the different procedures.

\begin{tabular}{|c|c|c|c|}
\hline $\begin{array}{l}\text { Groups of procedures }{ }^{1} \\
\text { (incubation periods) }\end{array}$ & $\mathrm{n}$ & $\begin{array}{c}\mathrm{N}^{0} \text { of } \\
\text { contaminations }^{2}\end{array}$ & $\begin{array}{c}\quad(\%) \\
\text { elimination } \\
\text { of viability }\end{array}$ \\
\hline Chemo-mechanical & 10 & 10 & 0 \\
\hline $\begin{array}{l}\text { Calen }^{\mathrm{TM}} \\
(7 \text { days })^{3}\end{array}$ & 10 & 3 & 70 \\
\hline $\begin{array}{l}\text { Calen }^{\mathrm{TM}} \\
(14 \text { days })^{3}\end{array}$ & 10 & 3 & 70 \\
\hline $\begin{array}{l}\text { PMCC-Calen }{ }^{\mathrm{TM}} \\
\text { (7 days) }\end{array}$ & 10 & 10 & 0 \\
\hline $\begin{array}{l}\text { PMCC-Calen } \\
(14 \text { days })^{3}\end{array}$ & 10 & 0 & 100 \\
\hline Positive control & 10 & 10 & 0 \\
\hline Total & 60 & 36 & 40 \\
\hline
\end{tabular}

${ }^{1}$ Control $(\mathrm{n}=10$ teeth) used to evaluate the external decontamination and chamber sealing procedures performed during experiments were not included in the Table. No growth was detected in this group; ${ }^{2}$ Number of teeth that remained with viable $E$. faecalis after the indicated procedures; ${ }^{3}$ No statistically significant differences were observed within the groups presenting elimination of $E$. faecalis viability $(\mathrm{p}>0.05)$. Significant differences were observed between groups presenting elimination of $E$. faecalis viability and groups without elimination of bacterial viability $(\mathrm{p}<0.00001)$, calculated by chi-square test. the different formulations of calcium hydroxide pastes (with or without $\mathrm{p}$-chlorophenol) were evaluated by the Student's t-test using Graphpad Prism software, version 4.0; Graph-Pad Software Inc., San Diego, CA, USA). Significance level was set at 5\% for all analyses.

\section{RESULTS}

The presence of viable microorganisms after the chemo-mechanical procedures, with or without incubation with intracanal medications, is shown in Table 1. Crown-down instrumentation allied to the chemo-mechanical protocol did not eliminate the enterococci grown inside dentine tissue. The chemo-mechanical treatment associated with intracanal medications presented varied capability to eliminate enterococci grown in contact with the dentin walls of the root canal system.

The use of Calen ${ }^{\mathrm{TM}}$ paste for 7 and 14 days induced the elimination of enterococci from 7 out of 10 teeth. PMCC-Calen ${ }^{\mathrm{TM}}$ demonstrated $100 \%$ elimination of enterococci viability only after maintenance of paste for 14 days. There were no statistically significant differences ( $>0.05)$ among these groups. However, PMCC-Calen ${ }^{\mathrm{TM}}$ maintained for 7 days was not capable to eliminate the viability of enterococci from the root canal systems. Statistically significant differences $(\mathrm{p}<0.00001)$ were observed between the groups of Calen ${ }^{\mathrm{TM}}$ for 7 and 14 days and PMCC Calen ${ }^{\mathrm{TM}}$ for 14 days, and the groups of chemo-mechanical preparation alone, control group, and PMCC-Calen ${ }^{\mathrm{TM}}$ maintained for 7 days.

Table 2 presents the diameter of growth inhibition zones observed by agar diffusion method. There were no significant differences $(p>0.05)$ in zone inhibition diameters when $\mathrm{p}$-chlorophenol was incorporated to calcium hydroxide pastes.

Table 2. Diameter of inhibition zones of Calen ${ }^{\mathrm{TM}}$ and PMCC Calen ${ }^{\mathrm{TM}}$ obtained by agar diffusion $\operatorname{method}^{1}$.

\begin{tabular}{lcc}
\hline Medications & $\begin{array}{c}\text { Zone inhibition } \\
(\mathrm{mm})^{2}\end{array}$ & $\begin{array}{c}\text { Standard } \\
\text { deviation }\end{array}$ \\
\hline Calen $^{\mathrm{TM}}(\mathrm{n}=10)$ & 8.6 & 0.70 \\
PMCC Calen $^{\mathrm{TM}}(\mathrm{n}=10)$ & 9.0 & 0.82 \\
\hline
\end{tabular}

${ }^{1}$ Total of ten independent experiments; ${ }^{2}$ Differences between means of zone inhibition diameters were not significant $(p=0.32)$. 


\section{DISCUSSION}

Microorganisms may remain viable after endodontic treatment inside dentinal tubules or in biofilms formed on apex area, and constitute a major cause of refractory diseases, requiring retreatment or other interventions to resolve endodontic infections (11). E. faecalis is a major bacterial species isolated from refractory endodontic infections (3) and was used in this study due to its high resistance to several antimicrobial agents (12). Unlike other studies in which bacterial cells grown in liquid media were used to contaminate endodontic space or agar plates for testing antimicrobial activity of pastes and cements (13), in this investigation the microorganisms were grown in liquid medium containing opened teeth to permit the penetration of the bacterial strain into root canal walls and tubular dentin matrix. The subsequent changes of fresh liquid medium every $24 \mathrm{~h}$ within $72 \mathrm{~h}$ might also have allowed the microorganisms to rearrange in biofilms, which is a structure known to confer resistance of microbial cells to different antimicrobial agents (6).

In this study, the presence of even undetectable (by usual microbiological methods) viable microorganisms that remained encased in distal regions of dentin tubules or accessory canals, after instrumentation and insertion of calcium hydroxide pastes, were able to grow in enterococcosel broth, a selective medium for enterococci.

Different procedures make part of endodontic treatment. Progressive instrumentation and shaping of root canal are capable to eliminate a large number of viable bacteria in root canal systems (14). In the present investigation, root canal shaping along with the use of $5.25 \%$ sodium hypochlorite as an irrigant was not capable to totally eliminate the viability of enterococci, that is $100 \%$ of growth, as reported elsewhere (15). Root canal filling represents an important step of endodontic therapy, due to its sealing properties, alongside the antimicrobial activity offered by some endodontic sealers and intracanal pastes (16). The use of sealers used in the obturation of root canal systems are object for future investigations. Due to the importance of calcium hydroxide pastes in endodontic treatment, and its use as interappointment medication, the present investigation demonstrated that calcium hydroxide pastes were capable to act synergistically to shaping and chemomechanical preparation. Inclusion of p-chlorophenol rendered the PMCC-Calen ${ }^{\mathrm{TM}}$ paste more effective when maintained for at least 14 days. Once phenolics are slightly acidic, the final $\mathrm{pH}$ of PMCC-Calen ${ }^{\mathrm{TM}}$ might interfere with dissociation of $\mathrm{Ca}(\mathrm{OH})_{2}$ on its lethal form to microorganisms (10), i.e. hydroxyl ions, influencing the viability of enterococci (17). In addition, PEG, used in both formulations employed in this study, have been used in sequestration of by products of enzyme oxidation of phenols in remediation of environmental phenol contaminations (18), and our results suggest that formulations containing PEG might also permit a slower release of the phenolic group, rendering the paste less active in initial periods of incubation in interior of root canal systems.

In the present investigation, due to the divergent results obtained with ex vivo experiments using different calcium hydroxide compositions, agar diffusion method was employed to ascertain the antimicrobial properties of both Calen ${ }^{\mathrm{TM}}$ and PMCC-Calen ${ }^{\mathrm{TM}}$ pastes. Unlike the effects observed after maintenance within the pulp space of contaminated teeth, the calcium hydroxide pastes with or without p-chlorophenol showed no differences in bacterial growth inhibition zones by the agar diffusion method, demonstrating that divergent results may be obtained by different techniques used in vitro to evaluate the antimicrobial activity among calcium hydroxide pastes.

Controversy in the clinical use of cresol, ormaline, and p-chlorophenol compounds has arisen in the last years. In a previous study, formocresol proved to be one of the most genotoxic compounds to Syrian hamster embryo cells. Nonetheless, no signs of chromosomal aberrations were detected after incubation of Syrian hamster embryo cells with p-chlorophenol (19). Thus, association of p-chlorophenol and calcium hydroxide pastes seem to be clinically safe when used as an interappointment medication, and is corroborated by the fact that cultured fibroblast cells demonstrated tolerance to calcium hydroxide used as an irrigant (20). Nevertheless, studies evaluating cytotoxicity of calcium hydroxide pastes with PEG and p-chlorophenol remain necessary to ascertain the clinical safety of calcium hydroxide formulations used as interappointment medications.

In conclusion, using this in vitro methodology, calcium hydroxide pastes can be considered as important adjuvant medications in the chemo-mechanical preparation of root canals, and are capable to eliminate E. faecalis, which is a microbial species recognized as 
resistant to calcium hydroxide. When associated with p-chlorophenol, $\mathrm{Ca}(\mathrm{OH})_{2}$ paste should be maintained for at least 14 days.

\section{RESUMO}

A eficácia das pastas de hidróxido de cálcio: Calen ${ }^{\circledR}$ e Calen$\mathrm{PMCC}^{\circledR}$ associadas ao preparo químico-mecânico, foi avaliada sobre Enterococcus faecalis cultivados no interior dos canais radiculares. Setenta incisivos foram inseridos em caldo TSB, esterilizados e contaminados com $\mathrm{E}$. faecalis. $\mathrm{O}$ meio de cultivo foi substituído a cada $24 \mathrm{~h}$, sendo incubados a $37^{\circ} \mathrm{C}$ por $72 \mathrm{~h}$. Após o preparo químico-mecânico, os canais radiculares foram preenchidos com Calen ${ }^{\circledR}$ ou Calen-PMCC ${ }^{\circledR}$ (7 ou 14 dias). As pastas foram removidas e os dentes inseridos em tubos contendo caldo Enterococcosel. A pasta Calen ${ }^{\circledR}$ (mantida por 7 ou 14 dias) induziu a eliminação dos enterococos em 70\% dos dentes, enquanto a pasta Calen-PMCC ${ }^{\circledR}$ induziu a eliminação em 100\% dos dentes, somente após a manutenção por 14 dias. Tais medicações foram significativamente mais efetivas $(p<0,001)$ do que o protocolo do preparo químico-mecânico e o Calen-PMCC ${ }^{\circledR}$ mantido por 7 dias, ambos incapazes de eliminar os enterococos. As pastas de hidróxido de cálcio demonstraram efeitos adjuvantes importantes na eliminação dos enterococos durante o preparo químico-mecânico dos sistemas de canais radiculares. Quando associada ao PMCC, as pastas de hidróxido de cálcio devem ser mantidas por pelo menos 14 dias.

\section{ACKNOWLEDGEMENTS}

This is work was supported by FAPERJ, CNPq, and CAPES. The authors Patricia E.P. Lana and Miriam F.Z. Scelza contributed equally to the study and to the preparation of this manuscript.

\section{REFERENCES}

1. Kakehashi S, Stanley HR, Fitzgerald RJ. The effects of surgical exposures of dental pulps in germ-free and conventional laboratory rats. Oral Surg Oral Med Oral Pathol 1965;20:340-349.

2. Jurcak JJ, Bellizzi R, Loushine J. Succesful single-visit endodontics during operation desert field. J Endod 1993;19:412-413.

3. Sunde PT, Olsen I, Debelian GJ, Tronstad L. Microbiota of periapical lesions refractory to endodontic therapy. J Endod 2002;28:304310.

4. Byström A, Claesson R, Sundqvist G. The antibacterial effect of camphorated paramonoclorofenol, camphorated phenol and calcium hydroxide in the treatment of infected root canals. Endod Dent Traumatol 1985;1:170-175.

5. Estrela C, Bamman LL, Pimenta FC, Pécora JD. Control of microorganisms in vitro by calcium hydroxide pastes. Int Endod J 2001;34:341-345.

6. Dunavant TR, Regan JD, Glickman GN, Solomon ES, Honeyman AL. Comparative evalution of endodontic irrigants against Enterococcus faecalis Biofilms. J Endod 2006;32:527-531.

7. Soares JA, Leonardo MR, Tanomaru Filho M, Silva LA, Ito IY. Residual antibacterial activity of chlorhexidine digluconate and camphorated p-monochlorophenol in calcium hydroxide-based root canal dressings. Braz Dent J 2007;18:8-15.

8. Ørstavik D, Haapasalo M. Disinfection by endodontic irrigants and dressings of experimentally infected dentinal tubules. Endod Dent Traumatol 1990;6:142-149.

9. Isenberg HD, Goldberg D, Sampson J. Laboratory studies with a selective Enterococcus medium. Appl Microbiol 1970;20:433436.

10. Gomes BPFA, Ferraz CCR, Garrido FD, Rosalen PL. Microbial susceptibility to $\mathrm{Ca}(\mathrm{OH})_{2}$ pastes and their vehicles. J Endod 2002;28:758-761.

11. Noguchi N, Noiri Y, Narimatsu M, Ebisu S. Identification and localization of extraradicular biofilm-forming bacteria associated with refractory endodontic pathogens. Appl Environ Microbiol 2005; 71:8738-8743.

12. Hunt CP. The emergence of enterococci as a cause of nosocomial infection. Br J of Biomed Sci 1998;55:149-156.

13. Sedgley CM, Lennan SL, Appelbe OK. Survival of Enterococcus faecalis in root canals ex vivo. Int Endod J 2005;38:735-742.

14. Card S, Sigurdsson A, Orstavik D, Trope M. The effectiveness of increased apical enlargement in reducing intracanal bacteria. J Endod 2002;28:779-83.

15. Shuping G, Ørstavik D, Sigurdsson A, Trope M. Reduction of intracanal bacteria using nickel-titanium rotary instrumentation various medications. J Endod 2000;26:751-755.

16. Leonardo MR, da Silva LA, Tanomaru Filho M, Bonifácio KC. In vitro evaluation of antimicrobial activity of sealers and pastes used in endodontics. J Endod 2000;26:391-394.

17. Tronstad L, Andreasen NJ, Hasselgren G, Kristerson L, Riis I. pH changes in dental tissues after root filling with calcium hydroxide. Int Endod J 1981;7:17-21.

18. Tonegawa M, Dec J, Bollag JM. Use of additive to enhance the removal of phenols from water treated with horseradish and hydrogen peroxide. J Environl Qual 2003;32:1222-1227.

19. Hagiwara M, Watanabe E, Barrett JC, Tsutsui T. Assessment of genotoxicity of 14 chemical agents used in dental practice: ability to induce chromosome aberrations in Syrian hamster embryo cells. Mutat Res 2006;28:111-120.

20. Desai S, Chandler N. Calcium hydroxide-based root canal sealers: a review. J Endod 2009;35:475-480. 